\title{
Effects of venoms on neutrophil respiratory burst: a major inflammatory function
}

\author{
Jamel El-Benna ${ }^{1} *$ (D), Margarita Hurtado-Nedelec ${ }^{1,2}$, Marie-Anne Gougerot-Pocidalo ${ }^{1,2}$, Pham My-Chan Dang ${ }^{1}$ \\ ${ }^{1}$ Université de Paris, INSERM-U1149, CNRS-ERL8252, Centre de Recherche sur I'Inflammation (CRI), Laboratoire d'Excellence Inflamex, Faculté de \\ Médecine Xavier Bichat, Paris, France. \\ ${ }^{2}$ AP-HP, Centre Hospitalier Universitaire Xavier Bichat, UF Dysfonctionnements Immunitaires, Paris, France.
}

\author{
Keywords: \\ Neutrophils \\ Venom \\ Inflammation \\ ROS \\ NADPH oxidase \\ PLA2 \\ L-amino acid oxidase \\ Mastoporan \\ Parabutoporin \\ Disintegrins
}

\begin{abstract}
Neutrophils play a pivotal role in innate immunity and in the inflammatory response. Neutrophils are very motile cells that are rapidly recruited to the inflammatory site as the body first line of defense. Their bactericidal activity is due to the release into the phagocytic vacuole, called phagosome, of several toxic molecules directed against microbes. Neutrophil stimulation induces release of this arsenal into the phagosome and induces the assembly at the membrane of subunits of the NAPDH oxidase, the enzyme responsible for the production of superoxide anion that gives rise to other reactive oxygen species (ROS), a process called respiratory burst. Altogether, they are responsible for the bactericidal activity of the neutrophils. Excessive activation of neutrophils can lead to extensive release of these toxic agents, inducing tissue injury and the inflammatory reaction. Envenomation, caused by different animal species (bees, wasps, scorpions, snakes etc.), is well known to induce a local and acute inflammatory reaction, characterized by recruitment and activation of leukocytes and the release of several inflammatory mediators, including prostaglandins and cytokines. Venoms contain several molecules such as enzymes (phospholipase A2, L-amino acid oxidase and proteases, among others) and peptides (disintegrins, mastoporan, parabutoporin etc.). These molecules are able to stimulate or inhibit ROS production by neutrophils. The present review article gives a general overview of the main neutrophil functions focusing on ROS production and summarizes how venoms and venom molecules can affect this function.
\end{abstract}




\section{Background}

Polymorphonuclear neutrophils (PMN) are the most abundant circulating leukocytes as they normally constitute 60 to $70 \%$ of white blood cells [1]. PMN have a key role in host defense against microbes as they are the first cells to migrate out of the circulation by a process called chemotaxis and are massively recruited at the infection site [2-5]. Once at the infection site, neutrophils recognize the pathogen via different receptors expressed at their cell surface, followed by engulfment of the microbe into a vacuole called the phagosome or phagolysosome [6-9]. Microbes are then killed by PMN through the release into the phagosome of highly toxic agents such as reactive oxygen species (ROS) and granule contents such as myeloperoxidase (MPO), glucosidases, proteases and anti-bacterial peptides $[10,11]$. Once the microbe is killed, neutrophils die by apoptosis, after which they are phagocytized and eliminated by the local macrophages through a process called efferocytosis, thereby cleaning the infection site. Thus, PMN are anti-inflammatory components of the innate immune system as their physiological role is to resolve the infection and the inflammation. Nevertheless, when PMN are excessively activated, the "cleaning task" cannot be completed and they become harmful to the surrounding tissues as they can induce cell injury and modification of cell homeostasis, metabolism and signaling [12-14].

Envenomation is a process by which a venom is inoculated into an organism by the bite or sting of different animal species (bees, wasps, scorpions, snakes etc.), inducing a localized inflammatory reaction characterized by the usual symptoms or redness, pain, heat and swelling, and in some cases, triggering an allergic response that can lead to death [15-17]. Venoms consist of a mixture of toxic agents with different properties and actions [1820]. A large number of toxic venom agents has been characterized, and consists of peptides and proteins that can modify host cells. They include phospholipase A2 (PLA2) that cleaves plasma membrane phospholipids to release arachidonic acid; L-amino acid oxidase (LAAO) that catalyzes the deamination of $\mathrm{L}$-amino acids to the corresponding a-ketoacids and production of hydrogen peroxide and ammonia; metalloproteinases that degrade membrane proteins; a family of peptides called disintegrins that bind to various cellular integrins; mastoparan that stimulates heterotrimeric G-proteins (Gi) and upregulate cellular functions; and parabutoporin thyat has antimicrobial properties and can modulate cell functions. These molecules are known to induce a variety of immune responses, including mastocyte degranulation, $\mathrm{T}$ cell activation, inflammasome activation in macrophages, and neutrophil activation [21-24]. In this review, after an overview of neutrophil ROS production, a key inflammatory function, we will summarize the most characterized effects of venom components on this neutrophil function and the known mechanism of action.

\section{Recruitment of neutrophils to the infection site and their activation}

Upon infection, keratinocytes, epithelial cells, tissue resident macrophages, and dendritic cells produce several soluble agents such as lipid mediators (platelet-activating factor (PAF), leukotriene B4 (LTB4), etc.), and several cytokines (IL-1, IL-8, IL-17, TNFa, etc.), which along with agents released by the pathogen (LPS, toxins, etc.), induce endothelial cell stimulation [6-8]. These agents promote the expression of E- and P-Selectins on the surface of endothelial cells. Resting circulating PMN detect these selectins via their respective ligands (L-selectin; CD62L) and start rolling onto the endothelial cells. Stimulated endothelial cells then express intercellular adhesion molecule-1 (ICAM-1), molecules that are recognized by neutrophil integrins (CD11b/CD18) and induce firm adhesion of the neutrophils to the endothelial cells. PMN then transmigrate through the endothelial cell junctions and move into the tissues towards the infection site, attracted by several chemoattractants such as PAF, LTB4, IL-8, the C5a fraction of the complement and the bacterial peptide fMLP (N-formyl-methionyl-leucyl-phenylalanine) (Figure 1). These chemoattractants induce signaling pathways that result in polarization of PMN and actin polymerization at the cell leading edge, positioning them towards the gradient of chemoattractants [6]. Chemotaxis is mainly controlled by the PI3Kinase and p38MAPKinase pathways, and by small G proteins such as Racl and Rac2 [6].

Once at the infectious site, PMN recognize microbe motifs via receptors of the Toll family [Toll-like receptors (TLR)] $[25,26]$. Human neutrophils express several TLR receptors that recognize various ligands, including TLR1 (recognizes lipoproteins), TLR2 (recognizes peptidoglycans from bacteria and fungi), TLR4 (recognizes LPS), TLR5 (recognizes flagellin), TLR6 (recognizes mycoplasma lipoprotein), TLR7 and TLR8 (recognize single strand virus RNA), and TLR9 (recognizes CpG bacterial DNA) $[25,26]$. These TLR agonists along with proinflammatory cytokines and agents found at the inflammatory site induce pre-activation of the neutrophils, a process called priming, which accelerates the phagocytosis of the microbe and its killing $[12,27,28]$. The binding of PMN to the microbe occurs through various opsonins such as the immunoglobulins G (IgG), which bind to FcgRIIA/CD32 and FcgRIIIB/CD16b, and the $\mathrm{C} 3 \mathrm{~b}$ and $\mathrm{C} 3 \mathrm{bi}$ proteins produced by activation of the complement, which bind to CR1/CD35 and CR3/CD18+CD11b, respectively $[3,11]$. The recognition is generally followed by engulfment of the microbe, which becomes surrounded by the membrane envelope, ultimately forming a vacuole called the phagosome or phagolysosome. Engulfment of the microbe triggers the PMN killing process that engages proteases, ROS and other toxic agents, leading to the death and destruction of the pathogen $[3,10,11]$. 


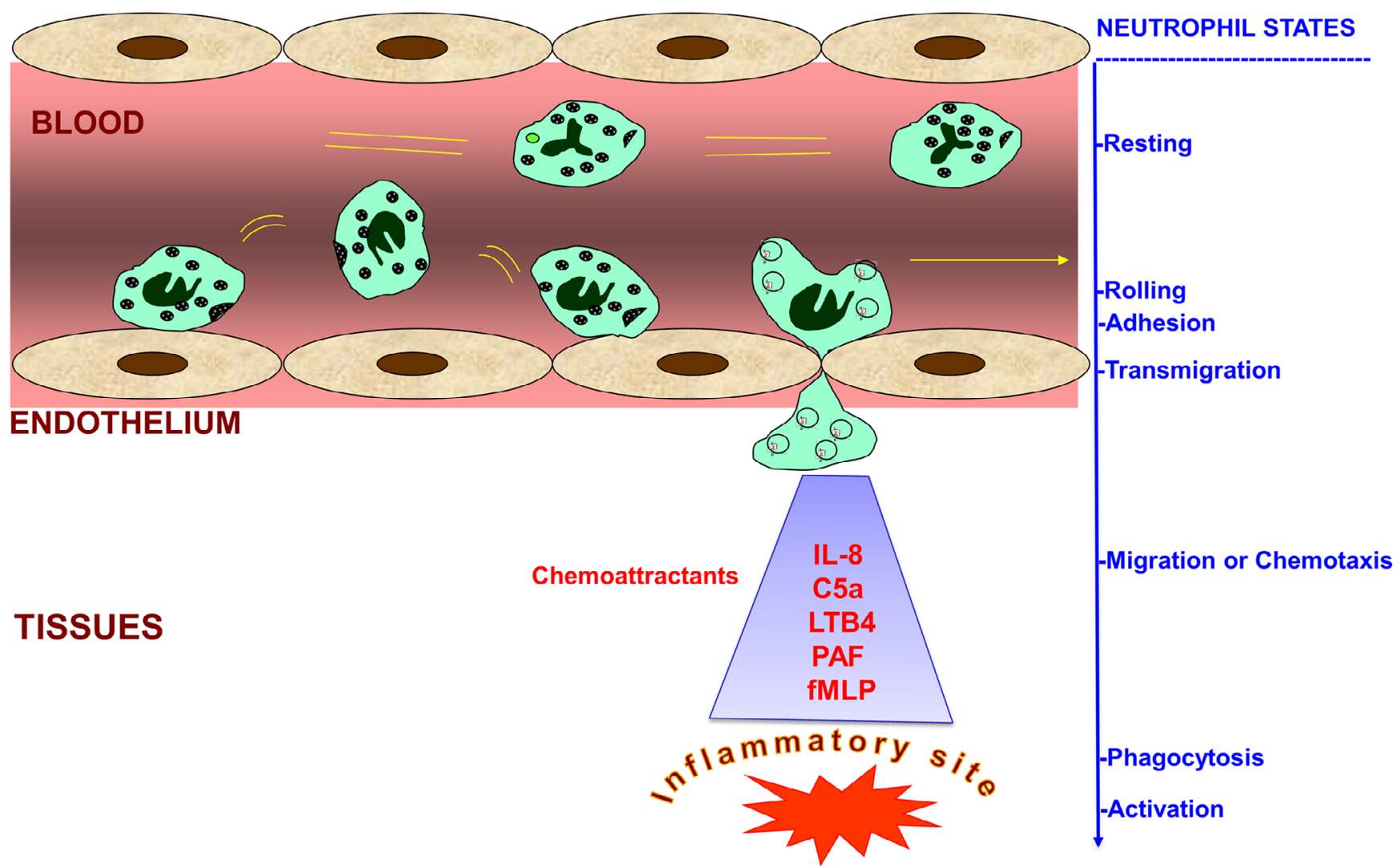

Figure 1. Migration of neutrophils from blood to the inflammatory site. Circulating neutrophils are in a resting state, also known as the dormant state. Upon inflammation, neutrophils start rolling, adhere and migrate to the inflammatory site, attracted by a multitude of chemoattractants such as IL-8, C5a, LTB4, PAF and $\mathrm{FMLP}$.

\section{Neutrophil arsenal of toxic agents}

In resting cells, $\mathrm{PMN}$ toxic agents are stored in different granules that have different composition and density [29, 30]. The most dense granules are called azurophil or primary granules as determined by Percoll-gradient ultracentrifugation, the specific granules or secondary granules are less dense than the former. Followed by the tertiary granules, also called gelatinase granules for their large content in gelatinase, and finally, the highly mobilizable secretory vesicles contain mainly plasma proteins. The detailed content of these granules is described in Table 1. The release of these granule contents upon cell activation is called degranulation and is an important neutrophil function for host defense against pathogens and inflammation $[9,11]$. Degranulation is induced upon phagocytosis but also by soluble agonists such as fMLP, phorbol myristate acetate (PMA), or calcium ionophores. Degranulation also allows expression of different receptors and the NADPH oxidase NOX2 at the cell membrane. It is controlled mainly by intracellular calcium, protein kinases such as PI3Kinase, p38MAPKinase and PKC and small $G$ proteins such as Racl $[31,32]$.

\section{ROS production by neutrophils}

Phagocytosis of a microbe stimulates PMN to produce ROS inside the phagosome (Figure 2). ROS include superoxide anion $\left(\mathrm{O}_{2}^{-}\right)$, hydrogen peroxide $\left(\mathrm{H}_{2} \mathrm{O}_{2}\right)$, hydroxyl radical $\left(\mathrm{OH}^{\circ}\right)$ and hypochlorous acid (HOCl) $[10,12,33]$. They are produced by phagocytes in a powerful process called "oxidative burst or respiratory burst", characterized by a rapid increase in oxygen and glucose consumption, and an abrupt ROS production. The first ROS molecule produced by PMN is superoxide anion $\left(\mathrm{O}_{2}^{-}\right)$, which is produced by the phagocyte NADPH oxidase through monovalent reduction of oxygen in the presence of an electron donor:

$$
\left(2 \mathrm{O}_{2}+\mathrm{NADPH} \rightarrow \mathbf{2} \mathrm{O}_{2}^{-}+\mathrm{NADP}^{+}+\mathrm{H}^{+}\right)
$$

While superoxide is not the most reactive, it is essential for the production of other ROS and bacterial killing. $\mathrm{O}_{2}^{-}$is then transformed into $\mathrm{H}_{2} \mathrm{O}_{2}$ by dismutation in the presence of protons $\mathrm{H}+$ (at acidic $\mathrm{pH}$ in the phagosome):

$$
\left(2 \mathrm{O}_{2}^{-\cdot}+2 \mathrm{H}^{+} \rightarrow \mathrm{H}_{2} \mathrm{O}_{2}+\mathrm{O}_{2}\right)
$$

a reaction that can be catalyzed by superoxide dismutase (SOD) in other locations. 
Table 1. Different human neutrophil granules and their contents [29, 30].

\begin{tabular}{|c|c|c|c|}
\hline $\begin{array}{l}\text { Azurophil granules } \\
\text { or primary granules } \\
\text { (very dense: }+++ \text { )* }\end{array}$ & $\begin{array}{l}\text { Specific granules } \\
\text { or secondary granules } \\
\text { (less dense: }++)^{*}\end{array}$ & $\begin{array}{c}\text { Gelatinase granules } \\
\text { or tertiary granules } \\
\text { (light: }+ \text { )* }\end{array}$ & $\begin{array}{l}\text { Secretory vesicles } \\
\text { (very light: }-/+) *\end{array}$ \\
\hline $\begin{array}{c}\text { Matrix } \\
\text { Myeloperoxidase (MPO)*** } \\
\text { Lysozyme } \\
\text { Elastase } \\
\text { Cathepsins } \\
\text { Proteinase-3 glucuronidase } \\
\text { defensins } \\
\text { BPI } \\
\text { Azurocidin/CAP37 } \\
\text { a-mannosidase } \\
\beta \text {-glucuronidase } \\
\beta \text {-glycerophosphatase } \\
\text { N-acetyl- } \beta \text {-gucosaminidase } \\
\text { Membrane } \\
\text { CD63 } \\
\text { CD68 } \\
\text { V-type H+-ATPase }\end{array}$ & $\begin{array}{c}\text { Matrix } \\
\text { Lactoferrin** } \\
\text { Lipocalin/NGAL** } \\
\text { Lysozyme Collagenase Gelatinase } \\
\text { Histaminase } \\
\text { hCAP-18 } \\
\text { Heparanase } \\
\text { Sialidase } \\
\text { VitaminB12-Binding protein } \\
\text { 32-microglobulin } \\
\text { Membrane } \\
\text { CD11b/CD18 } \\
\text { CD177 } \\
\text { CD15 } \\
\text { CD66 } \\
\text { CD67 } \\
\text { Gp91phox/p22phox } \\
\text { FPR (fMLP-R) } \\
\text { TNF-R } \\
\text { Fibronectin-R } \\
\text { Vitronectin-R } \\
\text { VAMP-2 } \\
\text { Laminin-R } \\
\text { activator-R }\end{array}$ & $\begin{array}{c}\text { Matrix } \\
\text { Gelatinase*** } \\
\text { Acetyltransferase Lysozyme } \\
\beta 2 \text {-microglobulin } \\
\text { Acetyltransferase } \\
\text { Membrane } \\
\text { CD11b/CD18 } \\
\text { CD177 } \\
\text { Gp91phox/p22phox } \\
\text { FPR (fMLP-R) } \\
\text { Fibronectin } \\
\text { VAMP2 } \\
\text { V-type H+-ATPase } \\
\text { Urokinase-type plasminogen } \\
\text { activator-R }\end{array}$ & $\begin{array}{c}\text { Matrix } \\
\text { Plasma proteins*** } \\
\text { Membrane } \\
\text { CD11b/CD18 } \\
\text { CD14 } \\
\text { CD16 } \\
\text { CD45 } \\
\text { Gp91phox/p22phox } \\
\text { FPR (fMLP-R) } \\
\text { SCAMP } \\
\text { Alkaline phosphatase } \\
\text { CR1 } \\
\text { V-type H+-ATPase } \\
\text { VAMP2 } \\
\text { C1q-R } \\
\text { Urokinase-type plasminogen } \\
\text { activator-R } \\
\text { DAF }\end{array}$ \\
\hline
\end{tabular}

*Density as obtained by Percoll gradient technique $[29,30]$

**The specific granule marker(s)

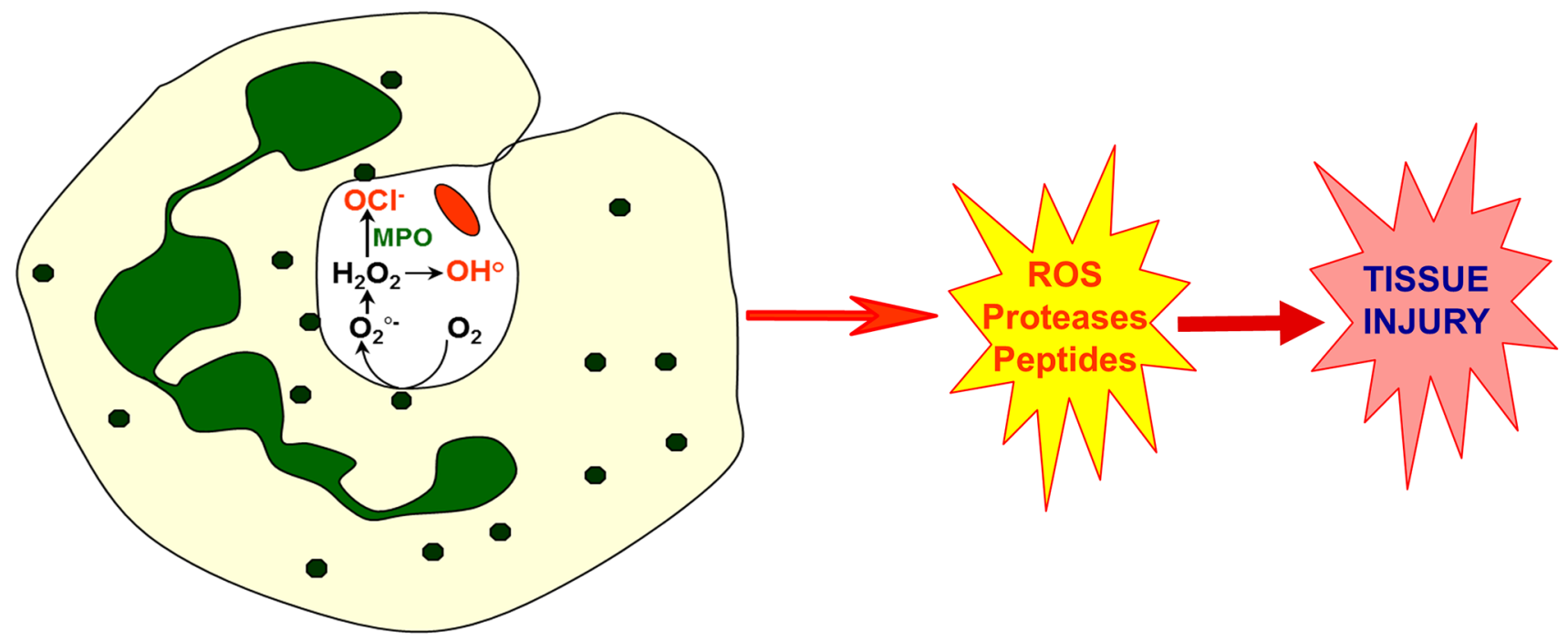

Figure 2. Activation of neutrophils. At the inflammatory site, neutrophils engulf the invading agent. Phagocytosis, in turn, induces a physiologically controlled activation of neutrophils, leading to the release of ROS and proteins inside the phagosome. However, excessive activation of neutrophils results in excessive release of ROS and granule contents in the extracellular space, contributing to tissue damage and inflammation. 
$\mathrm{H}_{2} \mathrm{O}_{2}$ and $\mathrm{O}_{2}{ }^{-}$can react together through the Haber-Weiss reaction in the presence of a transition metal (or the Fenton reaction in the presence of iron) to generate hydroxyl radical $\left(\mathrm{OH}^{\circ}\right)$ :

$\left(\mathrm{O}_{2}^{-}+\mathrm{H}_{2} \mathrm{O}_{2}(\right.$ or $\mathrm{Fe}++$ or $\left.\mathrm{Cu}++) \rightarrow \mathbf{O H}^{\circ}+\mathbf{O H}^{-}+\mathbf{O}_{2}\right)$,

Myeloperoxidase (MPO), released from azurophilic granules, catalyzes the transformation of $\mathrm{H}_{2} \mathrm{O}_{2}$ in the presence of a halogen $\left(\mathrm{Cl}^{-}, \mathrm{Br}^{-}, \mathrm{I}^{-}\right)$into very toxic molecules:

$$
\left(\mathrm{H}_{2} \mathrm{O}_{2}+\mathbf{H}^{+} \mathrm{Cl}^{-} \rightarrow \mathbf{H O C l}+\mathbf{H O}\right) \text {. }
$$

The hypochlorous acid $(\mathrm{HOCl})$ produced by this reaction reacts with amines resulting in chloramines:

$$
\left(\mathrm{H}^{+}+\mathrm{OCl}^{-}+\mathrm{R}-\mathrm{NH}_{2} \rightarrow \mathrm{R}-\mathrm{NHCl}+\mathrm{HO}\right) \text {. }
$$

\section{Structure and activation of the phagocyte NADPH oxidase}

The enzyme responsible for the first step leading to ROS production is called the respiratory burst oxidase or the phagocyte NADPH oxidase (NOX2) [12,33] which consists of several components, including the membrane cytochrome $\mathrm{b}_{558}$, a heterodimer composed of gp91phox/NOX2 and p22phox (phox: phagocyte oxidase), and the cytosolic p47phox, p67phox, p40phox and either Rac1 (in monocytes) or Rac2 (in neutrophils) (Figure 3). While dormant and spatially restricted in resting cells, the enzyme assembles at the membrane and becomes active to produce $\mathrm{O}_{2}^{-\cdot}$ when the cells are stimulated. In intact cells, NADPH oxidase activation is accompanied by phosphorylation of almost all of its components (p47phox, p67phox, p40phox, gp91phox and p22phox) [34], which facilitates new proteinprotein interactions and the assembly of the complex at the membrane of the phagosome. The vital importance of this enzyme is illustrated by a human genetic disorder called chronic granulomatous disease (CGD), which is due to gene mutation of one of the oxidase components (most frequently gp91phox and p47phox), and is associated with life-threatening bacterial and fungal infections [33]. However, excessive ROS release can also damage bystander host tissues (Figure 2), thereby amplifying inflammatory reactions [12-14].
NADPH oxidase activation in phagocytes can be induced by a large number of soluble and particulate factors such as opsonized bacteria, opsonized zymosan, formylated peptides such as (FMLP, C5a, PAF, calcium ionophores (ionomycin, A23187), and PKC activators like PMA [12]. The most studied agonists are FMLP and PMA. FMLP binds to its receptor, called FPR (formyl peptide receptor), which is a G-protein coupled receptor (GPCR) with seven trans-membrane domains [6, 35, 36]. The receptor activates heterotrimeric $G$ proteins (proteins binding guanosine triphosphate, GTP) and protein tyrosine kinases (PTK). The G proteins then activate membrane enzymes such as phospholipase C (PLC), PLA2, and phospholipase D (PLD), leading to the release of intracellular messengers [6, 35, 36]. PLC cleaves a membrane lipid, phosphatidylinositol 4,5-biphosphate (PIP2) into diacylglycerol (DAG) and inositol trisphosphate (IP3). IP3 is involved in the release of calcium from intracellular pools, while DAG activates protein kinase $\mathrm{C}(\mathrm{PKC})[6,35]$. Activation of PLD results in phosphatidic acid production from phosphatidylcholine. Activation of PLA2 leads to the cleavage of phospholipids to produce arachidonic acid, which can then be used as a substrate for leukotrienes and prostaglandins synthesis. Neutrophil activation is accompanied by the activation of many protein kinases such as PTK, PKA, $\mathrm{PKC}, \mathrm{AKT}$ and MAPKinase, which in turn phosphorylate many proteins with important cellular functions, including the NADPH oxidase components (Figure 4). In human neutrophils, various protein kinases have been implicated in the regulation of the NADPH oxidase activity, among them, the PKC family appears to play a major role after FMLF or PMA activation [34]. LPS and pro-inflammatory cytokines such as GM-CSF and TNFa, which alone do not activate NADPH oxidase but prime its activation by a secondary stimulus such as FMLP and C5a, induce partial phosphorylation of $\mathrm{p} 47 \mathrm{phox}$ within a specific peptide sequence and upregulate NADPH oxidase assembly $[12,27,28,37]$. Upon subsequent stimulation with FMLP or others, the phosphorylation of $\mathrm{p} 47 \mathrm{phox}$ on multiple serines

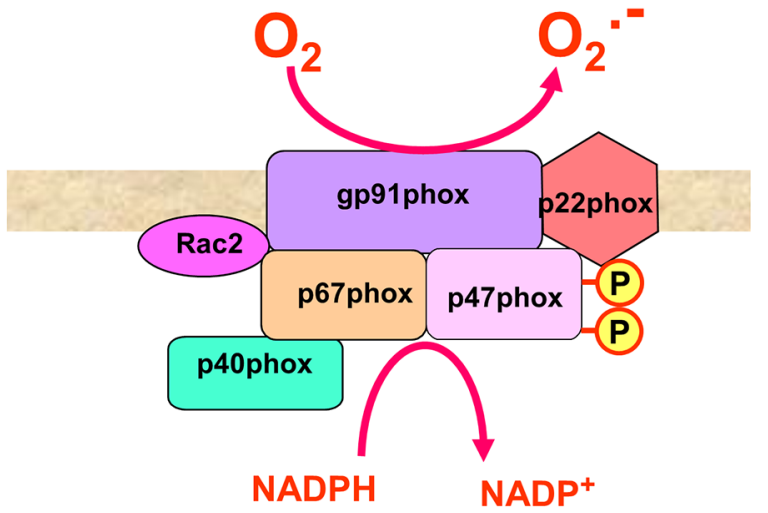

Phagosome or

Extracellular space

\section{Phagosome membrane \\ Or \\ Plasma membrane}

Cytosol

Figure 3. The NADPH oxidase complex. The active NADPH oxidase (NOX2) is composed of several cytosolic proteins (p67phox, $p 47 p h o x, p 40 p h o x$, rac2) and membrane-bound proteins (gp91phox and p22phox), initially referred to as cytochrome b558. The activated NADPH oxidase transfers an electron from the cytosolic NADPH to oxygen to form the radical, superoxide anion. 


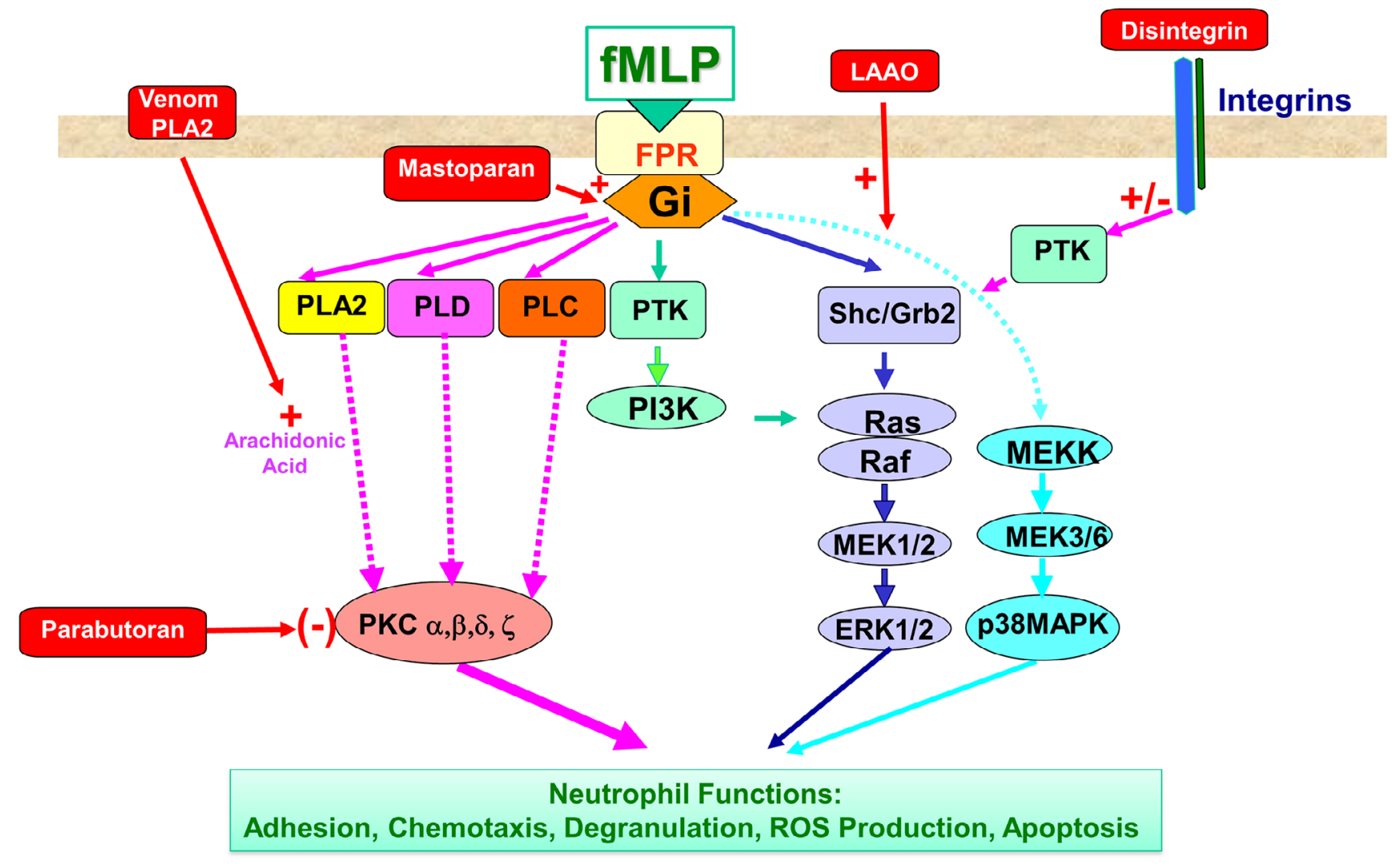

Figure 4. Molecular events underlying neutrophil activation and the effects of venom components. The fMLP peptide binds to its receptor called FPR (formyl peptide receptor), which activates heterotrimeric Gi proteins (proteins binding guanosine triphosphate, GTP) and tyrosine kinases. The G proteins then activate enzymes such as phospholipase C (PLC), phospholipase A2 (PLA2), phospholipase D (PLD), leading to the release of intracellular messengers, i.e., PLC catalyzes the formation of diacylglycerol (DAG) and inositol-triphosphate (IP3) from phosphatidylinositol 4,5-biphosphate (PIP2). IP3 is involved in the release of calcium from intracellular pools, while DAG activates protein kinase C (PKC). Activation of PLD results in phosphatidic acid production from phosphatidylcholine. Activation of PLA2 leads to the cleavage of membrane phospholipids to produce arachidonic acid, which can then be used as a substrate for leukotrienes and prostaglandins synthesis. FMLP induces activation of protein tyrosine kinases (PTK), which are upstream of the MAPKinase pathways (ERK1/2 and p38MAPKinase). All these kinases control neutrophil functions such as chemotaxis, degranulation, NADPH oxidase activation and apoptosis. The effect of venom components (PLA2, LAAO, disintegrin, mastoparan and parabutoparan) is shown in red.

induces conformational changes and interaction of the $\mathrm{SH} 3$ domains of p47phox with the proline-rich region of p22phox, resulting in assembly of the active enzyme $[12,38]$.

\section{Effects of crude venoms on neutrophil ROS production}

Venoms from different sources (bees, wasps, scorpions, snakes...) are a complex mixture of several agents such as enzymes (phospholipase A2, L-amino acid oxidase, proteases, cysteinerich secretory proteins), peptides (mastoporan, parabutoporin, disintegrins, etc.) and other toxins [18-20]. Envenomation can cause local and systemic effects characterized by an acute inflammatory reaction with leukocyte recruitment and activation and release of several mediators and cytokines [39-42]. Envenomation is known to be accompanied by egress of neutrophils from the bone marrow into the blood, increasing the number of circulating neutrophils [22,41]. This phenomenon has also been observed in animal models, as injection of a variety of venoms to mice or rats resulted in an increase of neutrophil population and a massive recruitment to the inoculation site $[24,41,43]$.
Envenomation is also known to be accompanied by a persistent oxidative stress in bite victims and animal envenomation models [44]. This was evidenced by the presence of lipid peroxidation by measuring the peroxidation product malondialdehyde (MDA) [45-47]. These data suggest a stimulation of ROS production from various sources such as neutrophils. Regarding the effect of envenomation on neutrophil ROS production in vivo, data are mainly obtained from the use of animal models. Indeed i.p. injection of Bothrops asper (BaV) and Bothrops jararaca $(\mathrm{BjV})$ venoms in mice increased phagocytosis and production of hydrogen peroxide ( $\mathrm{H} 2 \mathrm{O} 2)$ in the presence of PMA by polymorphonuclear and mononuclear peritoneal leukocytes [48]. In agreement with this finding, de Souza et al. [49] showed that Bothrops atrox snake venom injection in mice induced superoxide production by migrated neutrophils as assessed by nitroblue tetrazolium (NBT) reduction assay. Bothrops bilineata snaque venom was able to induce hydrogen peroxide production by human neutrophils [50]. Echis carinatus and Naja naja snake venoms induced NADPH oxidase activation and NETosis in human neutrophils [51]. It was also shown that 
Tityus zulianus and Tityus discrepans scorpion venoms induced hydrogen peroxide production by human neutrophils in vitro [52]. Scorpion venom induced ROS production is mediated by TLR4 as administration of a selective inhibitor (TAK-242 or Resatorvid) protected from inflammatory reaction and oxidative stress [53]. Indeed, TLR2, TL4 and CD14 of macrophages were shown to recognize scorpion venom [54].

\section{Effect of venom constituents on neutrophil ROS production}

\section{Effect of venom PLA2}

PLA2 cleaves membrane phospholipids at the sn-2-acyl ester bond, releasing arachidonic acid, a powerful inflammatory mediator [55]. Human cells express mainly an $85 \mathrm{kDa}$ cytosolic PLA2 and a $14 \mathrm{kDa}$ secretory PLA2. The cytosolic PLA2 is a key enzyme in neutrophil degranulation and ROS production. Interestingly, PLA2 interacts directly with the phagocyte NADPH oxidase and arachidonic acid itself is able to induce NADPH oxidase activation [56-59]. Several venoms (snake, bee, wasp and scorpion) contain different types of PLA2 [18, 20, 60]. These venom PLA2 are responsible for the inflammatory response induced by the venom [61-64], probably because of the degradation of the plasma membrane and the release of fatty acids such as arachidonic acid. Indeed, venom Asp49 PLA2 from Bothrops atrox venom induced degranulation and ROS production in neutrophils but also cytokine production in monocytes and macrophages, and degranulation in mast cells, thus inducing a strong inflammatory reaction $[65,66]$. The Lys49-PLA2 from the crude venom of Crotalus atrox was reported to induce intracellular calcium increase in human neutrophils [67], a process involved in the stimulation of several functions such as ROS production.

\section{Effect of venom L-amino acid oxidase}

L-amino acid oxidase (LAAO) is an enzyme that catalyzes the oxidative deamination of $\mathrm{L}$-amino acids to the corresponding alpha-ketoacids with production of $\mathrm{H}_{2} \mathrm{O}_{2}$ and ammonia [68-70]. LAAO is expressed in the venoms of many organisms, including in snakes [71-73]. LAAO has been shown to induce several biological effects such as hemolysis, edema, and activation of inflammatory leukocyte functions $[74,75]$. In neutrophils, LAAO isolated from snake venom induces chemotaxis, stimulates phagocytosis and release of several mediators [76-78], increasing integrin expression in human neutrophils and activation of other neutrophil functions (ROS production, MPO degranulation, cytokine production and NETs release) [76-78]. Interestingly, Paloschi et al. [79] showed that LAAO from Calloselasma rhodostoma snake venom activated NADPH oxidase in neutrophils.

\section{Effect of venom mastoporan}

Mastoparan is a tetradecapeptide toxin found in wasp venoms [80-82]. It was initially characterized as a good inducer of mast cell degranulation [80], and later was found to increase cytosolic calcium concentration and to stimulate IP3 production in human neutrophils [83]. These latter effects could be explained by the direct interaction of mastoparan with Gi proteins and stimulation of the GTPase activity, resulting in PLC activation, IP3 release and cytosolic calcium elevation $[84,85]$. Mastoporan induces neutrophil chemotaxis, degranulation, CR3 expression and superoxide production [85,86]. In a cell-free system, mastoporan was found to inhibit NADPH oxidase activation by binding to p67phox $[87,88]$; however, this inhibitory effect was not observed with intact neutrophils $[85,86]$. In vivo, mastoporan was able to induce inflammation by increasing TNF $\alpha$ and IL- $1 \beta$ levels and by recruiting neutrophils and macrophages [89].

\section{Effect of venom parabutoporin}

Parabutoporin is a peptide produced by Parabuthus schlechteri, a South African scorpion species [90]. It was initially known for its antibacterial and antifungal properties [90]. However, it was then shown to also stimulate neutrophil chemotaxis [91,92], degranulation, and to inhibit apoptosis [93,94]. It also inhibits neutrophil superoxide production [91,92], probably through its ability to serve as a PKC substrate, competing with the neutrophil p47phox, thereby inhibiting NADPH oxidase activation [95]. In summary, parabutoporin stimulates some neutrophil functions but inhibits NADPH oxidase activation. Thus, parabutoporin has both pro-inflammatory and anti-inflammatory effects.

\section{Effect of venom disintegrins}

Disintegrins are a family of small peptides, most of them containing an RGD (Arg-Gly-Asp) sequence, and are found in snake and other venoms $[96,97]$. Disintegrins selectively bind to different integrins, such as platelet integrins (alpha IIb, beta 3) to inhibit platelet aggregation, and to neutrophil integrins. Most disintegrins interact with integrins through the RGD sequence loop, resulting in an active site that modulates the integrin activity. It was shown that jarastatin and ocellatusin (two RGD-containing disintegrins) and alternagin-C (a nonRGD-disintegrin), two different disintegrins induced neutrophil migration via integrin activation, but inhibited fMLP- and IL-8-induced neutrophil chemotaxis [98-100]. Jarastatin was also shown to activate ERK1/2 and induce IL- 8 expression in neutrophils, while inhibiting apoptosis $[99,100]$. In contrast to the effects of Jarastatin, Rhodostomin, a different disintegrin, inhibits neutrophil adhesion to fibronectin and ROS production, suggesting an anti-inflammatory effect [101]. VLO5, a disintegrin isolated from Vipera lebetina obtusa venom, was found to activate the A9b1 integrin and to inhibit neutrophil apoptosis by increasing the expression of the proapoptotic protein $\mathrm{Bcl} 2$ [102]. Thus, disintegrins have opposite effects on neutrophils, having either a pro-inflammatory or an anti-inflammatory effect.

\section{Conclusion}

Neutrophils are key cells of the innate immunity, modulating the inflammatory reaction. Although they are required for 
host defense, their excessive activation can lead to excessive release of toxic agents such as ROS that can induce tissue injury and inflammation. Envenomation caused by different animal species (bees, wasps, scorpions, snakes...) is well known to induce a local and acute inflammatory reaction characterized by leukocytes recruitment and activation and the release of several mediators and cytokines. Venom components such as phospholipase A2, L-amino acid oxidase, disintegrins, mastoporan and parabutoporin are able to affect neutrophil ROS production. In this review, we attempted to describe the best characterized effects of the most studied venom components on neutrophil ROS production and the NADPH oxidase activation. Figure 4 summarizes the mechanisms of action of these different molecules on neutrophil pathways. Most venom components have a pro-inflammatory effect, but some can in addition inhibit specific neutrophil functions, exerting both a pro- and antiinflammatory effects. A multitude of other venom components are known and should be tested on neutrophil functions and pathways and on inflammatory reactions. The venom agents can be used as a powerful tool to modulate neutrophil functions for research or pharmacological purposes.

\section{Acknowledgements}

The authors wish to thank Martine Torres, PhD, for critical reading of the manuscript and editorial assistance.

\section{Availability of data and materials}

Not applicable.

\section{Funding}

This work was supported by grants from the Institut National de la Santé et de la Recherche Médicale (INSERM) and the Centre National de la Recherche Scientifique (CNRS), Université de Paris, Labex Inflamex, and Association Vaincre la Mucoviscidose (VLM).

\section{Competing interests}

The authors declare that they have no competing interest.

\section{Authors' contributions}

All authors wrote the review, read and approved the final manuscript.

\section{Ethics approval}

Not applicable.

\section{Consent for publication}

Not applicable.

\section{References}

1. Summers C, Rankin SM, Condliffe AM, Singh N, Peters AM, Chilvers ER. Neutrophil kinetics in health and disease. Trends Immunol. 2010 Aug;31(8):318-24. doi: 10.1016/j.it.2010.05.006. PubMed PMID: 20620114; PubMed Central PMCID: PMC2930213.

2. Mantovani A, Cassatella MA, Costantini C, Jaillon S. Neutrophils in the activation and regulation of innate and adaptive immunity. Nat Rev Immunol. 2011 Jul 25;11(8):519-31. doi: 10.1038/nri3024. PubMed PMID: 21785456.

3. Nauseef WM, Borregaard N. Neutrophils at work. Nat Immunol. 2014 Jul;15(7):602-11. doi: 10.1038/ni.2921. PubMed PMID: 24940954.

4. Malech HL, Deleo FR, Quinn MT. The role of neutrophils in the immune system: an overview. Methods Mol Biol. 2014;1124:3-10. doi: 10.1007/9781-62703-845-4_1. PubMed PMID: 24504942; PubMed Central PMCID: PMC6777345.

5. Soehnlein $O$, Lindbom L, Weber C. Mechanisms underlying neutrophilmediated monocyte recruitment. Blood. 2009 Nov 19;114(21):4613-23. doi: 10.1182/blood-2009-06-221630. PubMed PMID: 19696199.

6. Mócsai A, Walzog B, Lowell CA. Intracellular signalling during neutrophil recruitment. Cardiovasc Res. 2015 Aug 1;107(3):373-85. doi: 10.1093/ cvr/cvv159. PubMed PMID: 25998986; PubMed Central PMCID: PMC4502828.

7. Mócsai A. Diverse novel functions of neutrophils in immunity, inflammation, and beyond. J Exp Med. 2013 Jul 1;210(7):1283-99. doi: 10.1084/ jem.20122220. PubMed PMID: 23825232; PubMed Central PMCID: PMC3698517.

8. Witko-Sarsat V, Rieu P, Descamps-Latscha B, Lesavre P, HalbwachsMecarelli L. Neutrophils: molecules, functions and pathophysiological aspects. Lab Invest. 2000 May;80(5):617-53. doi: 10.1038/labinvest.3780067. PubMed PMID: 10830774.

9. Borregaard N. Neutrophils, from marrow to microbes. Immunity. 2010 Nov 24;33(5):657-70. doi: 10.1016/j.immuni.2010.11.011. PubMed PMID: 21094463.

10. Hampton MB, Kettle AJ, Winterbourn CC. Inside the neutrophil phagosome: oxidants, myeloperoxidase, and bacterial killing. Blood. 1998 Nov 1;92(9):3007-17. PubMed PMID: 9787133.

11. Nauseef WM. How human neutrophils kill and degrade microbes: an integrated view. Immunol Rev. 2007 Oct;219:88-102. doi: 10.1111/j.1600065X.2007.00550.x. PubMed PMID: 17850484.

12. El-BennaJ, Hurtado-Nedelec M, Marzaioli V, MarieJC, Gougerot-Pocidalo MA, Dang PMC. Priming of the neutrophil respiratory burst: role in host defense and inflammation. Immunol Rev. 2016 Sep;273(1):180-93. doi: 10.1111/imr.12447. PubMed PMID: 27558335.

13. Soehnlein $O$, Steffens $S$, Hidalgo A, Weber $C$. Neutrophils as protagonists and targets in chronic inflammation. Nat Rev Immunol. 2017 Apr;17(4):248261. doi: 10.1038/nri.2017.10. PubMed PMID: 28287106.

14. Babior BM. Phagocytes and oxidative stress. Am J Med. 2000 Jul;109(1):3344. doi:10.1016/s0002-9343(00)00481-2. PubMed PMID: 10936476.

15. Rivel M, Solano D, Herrera M, Vargas M, Villalta M, Segura Á, et al. Pathogenesis of dermonecrosis induced by venom of the spitting cobra, Naja nigricollis: an experimental study in mice. Toxicon. 2016 Sep 1;119:1719. doi: 10.1016/j.toxicon.2016.06.006. PubMed PMID: 27288896.

16. Echeverría S, Leiguez E, Guijas C, do Nascimento NG, Acosta O, Teixeira $C$, et al. Evaluation of pro-inflammatory events induced by Bothrops alternatus snake venom. Chem Biol Interact. 2018 Feb 1;281:24-31. doi: 10.1016/j.cbi.2017.12.022. PubMed PMID: 29248447.

17. Arruda VA, de Queiroz Guimarães A, Hyslop S, de Araújo PMF, Bon C, de Araújo AL. Bothrops lanceolatus (Fer de lance) venom stimulates leukocyte migration into the peritoneal cavity of mice. Toxicon. 2003 Jan;41(1):99107. doi: 10.1016/s0041-0101(02)00238-6. PubMed PMID: 12467667. 
18. Fry BG, Roelants K, Champagne DE, Scheib H, Tyndall JDA, King GF, et al. The toxicogenomic multiverse: convergent recruitment of proteins into animal venoms. Annu Rev Genomics Hum Genet. 2009;10:483-511. doi: 10.1146/annurev.genom.9.081307.164356. PubMed PMID: 19640225.

19. Vonk FJ, Casewell NR, Henkel CV, Heimberg AM, Jansen HJ, McCleary RJR, et al. The king cobra genome reveals dynamic gene evolution and adaptation in the snake venom system. Proc Natl Acad Sci U S A. 2013 Dec17;110(51):20651-6. doi: 10.1073/pnas.1314702110. PubMed PMID: 24297900 ; PubMed Central PMCID: PMC3870661.

20. Casewell NR, Wüster W, Vonk FJ, Harrison RA, Fry BG. Complex cocktails: the evolutionary novelty of venoms. Trends Ecol Evol. 2013 Apr;28(4):219-29. doi: 10.1016/j.tree.2012.10.020. PubMed PMID: 23219381.

21. Palm NW, Medzhitov R. Role of the inflammasome in defense against venoms. Proc Natl Acad Sci U S A. 2013 Jan 29;110(5):1809-14. doi: 10.1073/pnas.1221476110. PubMed PMID: 23297192 ; PubMed Central PMCID: PMC3562764.

22. Zuliani JP, Soares AM, Gutiérrez JM. Polymorphonuclear neutrophil leukocytes in snakebite envenoming. Toxicon. 2020 Nov;187:188-197. doi: 10.1016/j.toxicon.2020.09.006. PubMed PMID: 32956681.

23. Zuliani JP, Gutiérrez JM, Casais e Silva LL, Coccuzzo Sampaio S, Lomonte $B$, Pereira Teixeira C de FP. Activation of cellular functions in macrophages by venom secretory Asp-49 and Lys-49 phospholipases A(2). Toxicon. 2005 Oct;46(5):523-32. doi:10.1016/j.toxicon.2005.06.017. PubMed PMID: 16085208.

24. de Paula L, Santos WF, Malheiro A, Carlos D, Faccioli LH. Differential modulation of cell recruitment and acute edema in a model of Polybia paulista venom-induced inflammation. Int Immunopharmacol. 2006 Feb;6(2):182-9. doi: 10.1016/j.intimp.2005.08.002. PubMed PMID: 16399622.

25. Akira S, Takeda K. Toll-like receptor signalling. Nat Rev Immunol. 2004 Jul;4(7):499-511. doi: 10.1038/nri1391. PubMed PMID: 15229469.

26. Beutler B, Hoebe K, Du X, Ulevitch RJ. How we detect microbes and respond to them: the Toll-like receptors and their transducers. J Leukoc Biol. 2003 Oct;74(4):479-85. doi: 10.1189/jlb.0203082. PubMed PMID: 12960260.

27. Makni-Maalej K, Boussetta T, Hurtado-Nedelec M, Belambri SA, Gougerot-Pocidalo MA, El-Benna J. The TLR7/8 agonist CL097 primes $\mathrm{N}$-formyl-methionyl-leucyl-phenylalanine-stimulated NADPH oxidase activation in human neutrophils: critical role of $\mathrm{p} 47$ phox phosphorylation and the proline isomerase Pin1. J Immunol. 2012 Nov 1;189(9):4657-65. doi: 10.4049/jimmunol.1201007. Epub 2012 Sep 21. PubMed PMID: 23002436.

28. Liu M, Bedouhene S, Hurtado-Nedelec M, Pintard C, Dang PMC, Yu S, et al. The prolyl isomerase Pin1 controls lipopolysaccharide-induced priming of NADPH oxidase in human neutrophils. Front Immunol. 2019 Nov 1;10:2567. doi: 10.3389/fimmu.2019.02567. eCollection 2019. PubMed PMID: 31736979 ; PubMed Central PMC6839773.

29. Faurschou M, Borregaard N. Neutrophil granules and secretory vesicles in inflammation. Microbes Infect. 2003 Nov;5(14):1317-27. doi: 10.1016/j. micinf.2003.09.008. PubMed PMID: 14613775.

30. Cowland JB, Borregaard N. Granulopoiesis and granules of human neutrophils. Immunol Rev. 2016 Sep;273(1):11-28. doi: 10.1111/imr.12440. PubMed PMID: 27558325.

31. Lacy P, Eitzen G. Control of granule exocytosis in neutrophils. Front Biosci. 2008 May 1;13:5559-70. doi: 10.2741/3099. PubMed PMID: 18508605.

32. Lacy P. Mechanisms of degranulation in neutrophils. Allergy Asthma Clin Immunol. 2006 Sep 15;2(3):98-108. doi: 10.1186/1710-1492-2-3-98. PubMed PMID: 20525154 ; PubMed Central PMCID: PMC2876182.

33. El-Benna J, Dang PMC, Gougerot-Pocidalo MA, Elbim C. Phagocyte NADPH oxidase: a multicomponent enzyme essential for host defenses. Arch Immunol Ther Exp (Warsz). May-Jun 2005;53(3):199-206. PubMed PMID: 15995580.

34. Belambri SA, Rolas L, Raad H, Hurtado-Nedelec M, Dang PMC, El-Benna J. NADPH oxidase activation in neutrophils: role of the phosphorylation of its subunits. Eur J Clin Invest. 2018 Nov;48 Suppl 2:e12951. doi: 10.1111/ eci.12951. PubMed PMID: 29757466.
35. Ye RD, Boulay F, Wang JM, Dahlgren C, Gerard C, Parmentier M, et al. International Union of Basic and Clinical Pharmacology. LXXIII. Nomenclature for the formyl peptide receptor (FPR) family. Pharmacol Rev. 2009 Jun;61(2):119-61. doi: 10.1124/pr.109.001578. PubMed PMID: 19498085 ; PubMed Central PMCID: PMC2745437.

36. Rabiet MJ, Huet E, Boulay F. The $\mathrm{N}$-formyl peptide receptors and the anaphylatoxin C5a receptors: an overview. Biochimie. 2007 Sep;89(9):1089106. doi: 10.1016/j.biochi.2007.02.015. PubMed PMID: 17428601 ; PubMed Central PMCID: PMC7115771.

37. Dang PMC, Stensballe A, Boussetta T, Raad H, Dewas C, Kroviarski Y, et al. A specific $\mathrm{p} 47$ phox-serine phosphorylated by convergent MAPKs mediates neutrophil NADPH oxidase priming at inflammatory sites. J Clin Invest. 2006 Jul;116(7):2033-43. doi: 10.1172/JCI27544. PubMed PMID: 16778989 ; PubMed Central PMCID: PMC1479423.

38. Boussetta T, Gougerot-Pocidalo MA, Hayem G, Ciappelloni S, Raad $H$, Arabi Derkawi $R$, et al. The prolyl isomerase Pin1 acts as a novel molecular switch for TNF-alpha-induced priming of the NADPH oxidase in human neutrophils. Blood. 2010 Dec 23;116(26):5795-802. doi: 10.1182/ blood-2010-03-273094. PubMed PMID: 20956805. PubMed Central PMCID: PMC3031377.

39. Zamuner SR, Zuliani JP, Fernandes CM, Gutiérrez JM, de Fátima Pereira Teixeira C. Inflammation induced by Bothrops asper venom: release of proinflammatory cytokines and eicosanoids, and role of adhesion molecules in leukocyte infiltration. Toxicon. 2005 Dec 1;46(7):806-13. doi: 10.1016/j. toxicon.2005.08.011. PubMed PMID: 16198389.

40. Borges CM, Silveira MR, Aparecida M, Beker CL, Freire-Maia L, Teixeira MM. Scorpion venom-induced neutrophilia is inhibited by a PAF receptor antagonist in the rat. J Leukoc Biol. 2000 Apr;67(4):515-9. doi: 10.1002/ jlb.67.4.515. PubMed PMID: 10770284.

41. Coelho FM, Pessini AC, Coelho AM, Pinho VS, Souza DG, Arantes EC, et al. Platelet activating factor receptors drive $\mathrm{CXC}$ chemokine production, neutrophil influx and edema formation in the lungs of mice injected with Tityus serrulatus venom. Toxicon. 2007 Sep 1;50(3):420-7. doi: 10.1016/j. toxicon.2007.04.009. PubMed PMID: 17532358.

42. Reis MB, Zoccal KF, Gardinassi LG, Faccioli LH. Scorpion envenomation and inflammation: beyond neurotoxic effects. Toxicon. 2019 Sep;167:174179. doi:10.1016/j.toxicon.2019.06.219. Epub 2019 Jun 20. PubMed PMID: 31228480.

43. Wanderley CWS, Silva CMS, Wong DVT, Ximenes RM, Morelo DFC, Cosker $\mathrm{F}$, et al. Bothrops jararacussu snake venom-induces a local inflammatory response in a prostanoid- and neutrophil-dependent manner. Toxicon. 2014 Nov;90:134-47. doi: 10.1016/j.toxicon.2014.08.001. Epub 2014 Aug 12. PubMed PMID: 25127849.

44. Sunitha K, Hemshekhar M, Thushara RM, Santhosh MS, Sundaram MS, Kemparaju K, et al. Inflammation and oxidative stress in viper bite: an insight within and beyond. Toxicon. 2015 May;98:89-97. doi: 10.1016/j. toxicon.2015.02.014. Epub 2015 Feb 26. PubMed PMID: 25727382.

45. Al Asmari A, Al Moutaery K, Manthari RA, Khan HA. Time-course of lipid peroxidation in different organs of mice treated with Echis pyramidum snake venom. J Biochem Mol Toxicol. 2006;20(2):93-5. doi: 10.1002/ jbt.20121. PubMed PMID:16615057.

46. da Silva JG, da Silva Soley B, Gris V, do Rocio Andrade Pires A, Caderia SMSC, Eler GJ, et al. Effects of the Crotalus durissus terrificus snake venom on hepatic metabolism and oxidative stress. J Biochem Mol Toxicol. 2011 May-Jun;25(3):195-203. doi: 10.1002/jbt.20376. Epub 2010 Nov 15. PubMed PMID: 21671311.

47. Sebastin Santhosh M, Hemshekhar M, Thushara RM, Devaraja S, Kemparaju K, Girish KS. Vipera russelli venom-induced oxidative stress and hematological alterations: amelioration by crocin a dietary colorant. Cell Biochem Funct. 2013 Jan;31(1):41-50. doi: 10.1002/cbf.2858. Epub 2012 Aug 15. PubMed PMID: 22893269.

48. Zamuner SR, Gutiérrez JM, Muscará MN, Teixeira SA, Teixeira CF. Bothrops asper and Bothrops jararaca snake venoms trigger microbicidal functions of peritoneal leukocytes in vivo. Toxicon. 2001 Oct;39(10):1505-13. doi:10.1016/s0041-0101(01)00123-4. PubMed PMID: 11478958. 
49. de Souza CA, Kayano AM, Setúbal SS, Pontes AS, Furtado JL, Kwasniewski $\mathrm{FH}$, et al. Local and systemic biochemical alterations induced by Bothrops atrox snake venom in mice. J Venom Res. 2012;3:28-34. Epub 2012 Oct 25. PudMed PMID: 23487552; PMCID: PMC3595125.

50. Setubal S da S, Pontes AS, Nery NM, Bastos JSF, Castro OB, Pires WL, et al. Effect of Bothrops bilineata snake venom on neutrophil function. Toxicon. 2013 Dec 15;76:143-9. doi: 10.1016/j.toxicon.2013.09.019. PubMed PMID: 24080355.

51. Swethakumar B, NaveenKumar SK, Girish KS, Kemparaju K. The action of Echis carinatus and Naja naja venoms on human neutrophils; an emphasis on NETosis. Biochim Biophys Acta Gen Subj. 2020 Jun;1864(6):129561. doi:10.1016/j.bbagen.2020.129561. Epub 2020 Feb 15. PubMed PMID: 32068016.

52. Borges A, Op den Camp HJM, De Sanctis JB. Specific activation of human neutrophils by scorpion venom: a flow cytometry assessment. Toxicol In Vitro. 2011 Feb;25(1):358-67. doi: 10.1016/j.tiv.2010.10.009. PubMed PMID: 20969948.

53. Khemili D, Laraba-Djebari F, Hammoudi-Triki D. Involvement of Toll-like Receptor 4 in neutrophil-mediated inflammation, oxidative stress and tissue damage induced by scorpion venom. Inflammation. 2020 Feb;43(1):155-167. doi:10.1007/s10753-019-01105-y. PubMed PMID: 31654297.

54. Zoccal KF, Bitencourt C da S, Paula-Silva FWG, Sorgi CA, de Castro Figueiredo Bordon K, Arantes EC, et al. TLR2, TLR4 and CD14 recognize venom-associated molecular patterns from Tityus serrulatus to induce macrophage-derived inflammatory mediators. PLoS One. 2014 Feb 7;9(2):e88174. doi:10.1371/journal.pone.0088174. PubMed PMID: 24516606; PubMed PMCID: PMC3917877.

55. Burke JE, Dennis EA. Phospholipase A2 structure/function, mechanism, and signaling. J Lipid Res. 2009 Apr;50 Suppl(Suppl):S237-42. doi: 10.1194/ jlr.R800033-JLR200. PubMed PMID: 19011112. PubMed Central PMCID: PMC2674709.

56. Tithof PK, Peters-Golden M, Ganey PE. Distinct phospholipases A2 regulate the release of arachidonic acid for eicosanoid production and superoxide anion generation in neutrophils. J Immunol. 1998 Jan 15;160(2):953-60. PubMed PMID: 9551934.

57. Marshall J, Krump E, Lindsay T, Downey G, Ford DA, Zhu P, et al. Involvement of cytosolic phospholipase A2 and secretory phospholipase A2 in arachidonic acid release from human neutrophils. J Immunol. 2000 Feb15;164(4):208491. doi: 10.4049/jimmunol.164.4.2084. PubMed PMID: 10657662.

58. Shmelzer Z, Karter M, Eisenstein M, Leto TL, Hadad N, Ben-Menahem $D$, et al. Cytosolic phospholipase A2alpha is targeted to the p47phox-PX domain of the assembled NADPH oxidase via a novel binding site in its C2 domain. J Biol Chem. 2008 Nov 14;283(46):31898-908. doi: 10.1074/ jbc.M804674200. PubMed PMID: 18765662.

59. Levy $R$. The role of cytosolic phospholipase A2-alfa in regulation of phagocytic functions. Biochim Biophys Acta. 2006 Nov;1761(11):1323-34. doi: 10.1016/j.bbalip.2006.09.004. PubMed PMID: 17046321.

60. Zambelli VO, Picolo G, Fernandes CAH, Fontes MRM, Cury Y. Secreted phospholipases $A_{2}$ from animal venoms in pain and analgesia. Toxins (Basel). 2017 Dec 19;9(12):406. doi: 10.3390/toxins9120406. PubMed PMID: 29311537 ; PubMed Central PMCID: PMC5744126.

61. Perez-Riverol A, Lasa AM, Dos Santos-Pinto JRA, Palma MS. Insect venom phospholipases $A 1$ and $A 2$ : roles in the envenoming process and allergy. Insect Biochem Mol Biol. 2019 Feb;105:10-24. doi: 10.1016/j. ibmb.2018.12.011. PubMed PMID: 30582958.

62. Zuliani JP, Fernandes CM, Zamuner SR, Gutiérrez JM, Teixeira CFP. Inflammatory events induced by Lys-49 and Asp-49 phospholipases A2 isolated from Bothrops asper snake venom: role of catalytic activity. Toxicon. 2005 Mar 1;45(3):335-46. doi: 10.1016/j.toxicon.2004.11.004. PubMed PMID: 15683872.

63. Cardoso DF, Lopes-Ferreira M, Faquim-Mauro EL, Macedo MS, Farsky $\mathrm{SH}$. Role of crotoxin, a phospholipase $\mathrm{A} 2$ isolated from Crotalus durissus terrificus snake venom, on inflammatory and immune reactions. Mediators Inflamm. 2001 Jun;10(3):125-33. doi: 10.1080/09629350124986. PubMed PMID: 11545249 ; PubMed Central PMCID: PMC1781704.
64. Silvestrini AVP, de Macedo LH, de Andrade TAM, Mendes MF, Pigoso AA, Mazzi MV. Intradermal application of crotamine induces inflammatory and immunological changes in vivo. Toxins (Basel). 2019 Jan 14;11(1):39. doi: 10.3390/toxins11010039. PubMed PMID: 30646542 ; PubMed Central PMCID: PMC6357061.

65. Setúbal S da S, Pontes AS, Nery NM, Rego CMA, Santana HM, de Lima AM, et al. Human neutrophils functionality under effect of an Asp49 phospholipase $A_{2}$ isolated from Bothrops atrox venom. Toxicon X. 2020 Mar 18;6:100032. doi: 10.1016/j.toxcx.2020.100032. PMID: 32550587; PMCID: PMC7286099.

66. Ranéia e Silva PA, da Costa Neves A, da Rocha CB, Moura-da-Silva AM, Faquim-Mauro EL. Differential macrophage subsets in muscle damage induced by a K49-PLA from Bothrops jararacussu venom modulate the time course of the regeneration process. Inflammation. 2019 Oct;42(5):15421554. doi: 10.1007/s10753-019-01016-y. PubMed PMID: 31123944.

67. Sultan MT, Li HM, Lee YZ, Lim SS, Song DK. Identification of Lys49PLA2 from crude venom of Crotalus atrox as a human neutrophil-calcium modulating protein. Korean J Physiol Pharmacol. 2016 Mar;20(2):177-83. doi: 10.4196/kjpp.2016.20.2.177. PubMed PMID: 26937214; PubMed Central PMCID: PMC4770108.

68. Zuliani JP, Kayano AM, Zaqueo KD, Neto AC, Sampaio SV, Soares AM, et al. Snake venom L-amino acid oxidases: some consideration about their functional characterization. Protein Pept Lett. 2009;16(8):908-12. doi: 10.2174/092986609788923347. PubMed PMID: 19689417.

69. Izidoro LFM, Sobrinho JC, Mendes MM, Costa TR, Grabner AN, Rodrigues VM, et. Snake venom L-amino acid oxidases: trends in pharmacology and biochemistry. Biomed Res Int. 2014;2014:196754. doi: 10.1155/2014/196754. PubMed PMID: 24738050; PubMed Central PMCID: PMC3971498.

70. Torii S, Naito M, Tsuruo T. Apoxin I, a novel apoptosis-inducing factor with L-amino acid oxidase activity purified from Western diamondback rattlesnake venom. J Biol Chem. 1997 Apr 4;272(14):9539-42. doi: 10.1074/ jbc.272.14.9539. PubMed PMID: 9083096.

71. Ali SA, Stoeva S, Abbasi A, Alam JM, Kayed R, Faigle M, et al. Isolation, structural, and functional characterization of an apoptosis-inducing L-amino acid oxidase from leaf-nosed viper (Eristocophis macmahoni) snake venom. Arch Biochem Biophys. 2000 Dec 15;384(2):216-26. doi: 10.1006/abbi.2000.2130. PubMed PMID: 11368308.

72. Braga MDM, Martins AMC, Amora DN, de Menezes DB, Toyama MH, Toyama DO, et al. Purification and biological effects of $L$-amino acid oxidase isolated from Bothrops insularis venom. Toxicon. 2008 Feb;51(2):199-207. doi: 10.1016/j.toxicon.2007.09.003. PubMed PMID: 17983639.

73. Toyama MH, Toyama DO, Passero LFD, Laurenti MD, Corbett CE, Tomokane TY, et al. Isolation of a new L-amino acid oxidase from Crotalus durissus cascavella venom. Toxicon. 2006 Jan;47(1):47-57. doi: 10.1016/j. toxicon.2005.09.008. PubMed PMID: 16307769.

74. Izidoro LF, Ribeiro MC, Souza GR, Sant'Ana CD, Hamaguchi A, HomsiBrandeburgo MI, et al. Biochemical and functional characterization of an L-amino acid oxidase isolated from Bothrops pirajai snake venom. Bioorg Med Chem. 2006 Oct 15;14(20):7034-43. doi: 10.1016/j.bmc.2006.06.025. PubMed PMID: 16809041.

75. Wei XL, Wei JF, Li T, Qiao LY, Liu YL, Huang T, et al. Purification, characterization and potent lung lesion activity of an L-amino acid oxidase from Agkistrodon blomhoffii ussurensis snake venom. Toxicon. 2007 Dec 15;50(8):1126-39. doi: 10.1016/j.toxicon.2007.07.022. PubMed PMID: 17854853.

76. Pontes AS, da Silva Setúbal S, Xavier CV, Lacouth-Silva F, Kayano AM, Pires WL, et al. Effect of L-amino acid oxidase from Calloselasma rhodosthoma snake venom on human neutrophils. Toxicon. 2014 Mar;80:27-37. doi: 10.1016/j.toxicon.2013.12.013. PubMed PMID: 24462716.

77. Pontes AS, da Silva Setúbal S, Nery NM, da Silva FS, da Silva SD, Fernandes CFC, et. p38 MAPK is involved in human neutrophil chemotaxis induced by L-amino acid oxidase from Calloselasma rhodosthoma. Toxicon. 2016 Sep 1;119:106-16. doi: 10.1016/j.toxicon.2016.05.013. PubMed PMID: 27242041. 
78. Pereira-Crott LS, Casare-Ogasawara TM, Ambrosio L, Chaim LFP, de Morais FR, Cintra ACO, et. Bothrops moojeni venom and BmooLAAO-I downmodulate CXCL8/IL-8 and CCL2/MCP-1 production and oxidative burst response, and upregulate $\mathrm{CD} 11 \mathrm{~b}$ expression in human neutrophils. Int Immunopharmacol. 2020 Mar;80:106154. doi: 10.1016/j. intimp.2019.106154. Epub 2020 Jan 18. PMID: 31962250.

79. Paloschi MV, Boeno CN, Lopes JA, Eduardo dos Santos da Rosa A, Pires WL, Pontes AS, et. Role of I-amino acid oxidase isolated from Calloselasma rhodostoma venom on neutrophil NADPH oxidase complex activation. Toxicon. 2018 Apr;145:48-55. doi: 10.1016/j.toxicon.2018.02.046. PubMed PMID: 29499246.

80. Hirai Y, Yasuhara T, Yoshida H, Nakajima T, Fujino M, Kitada C. A new mast cell degranulating peptide "mastoparan" in the venom of Vespula lewisii. Chem Pharm Bull (Tokyo). 1979 Aug;27(8):1942-4. doi: 10.1248/ cpb.27.1942. PMID: 540362.

81. Nakajima T, Uzu S, Wakamatsu K, Saito K, Miyazawa T, Yasuhara T, et al. Amphiphilic peptides in wasp venom. Biopolymers. 1986;25 Suppl:S115-21. PubMed PMID: 3779021

82. de Souza BM, da Silva AVR, Resende VMF, Arcuri HA, Dos Santos Cabrera MP, Ruggiero Neto J, et al. Characterization of two novel polyfunctional mastoparan peptides from the venom of the social wasp Polybia paulista. Peptides. 2009 Aug;30(8):1387-95. doi: 10.1016/j.peptides.2009.05.008. PubMed PMID: 19463874.

83. Perianin A, Snyderman R. Mastoparan, a wasp venom peptide, identifies two discrete mechanisms for elevating cytosolic calcium and inositol trisphosphates in human polymorphonuclear leukocytes. J Immunol. 1989 Sep 1;143(5):1669-73. PubMed PMID: 2760463.

84. Weingarten R, Ransnäs L, Mueller H, Sklar LA, Bokoch GM. Mastoparan interacts with the carboxyl terminus of the alpha subunit of $\mathrm{Gi}$. J Biol Chem. 1990 Jul 5;265(19):11044-9. PubMed PMID: 2113529.

85. Surve CR, To JY, Malik S, Kim M, Smrcka AV. Dynamic regulation of neutrophil polarity and migration by the heterotrimeric $G$ protein subunits Gai-GTP

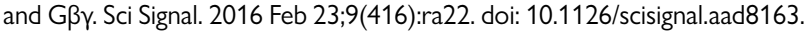
PubMed PMID: 26905427 ; PubMed Central PMCID: PMC6364554.

86. Norgauer J, Eberle M, Lemke HD, Aktories K. Activation of human neutrophils by mastoparan. Reorganization of the cytoskeleton, formation of phosphatidylinositol 3,4,5-trisphosphate, secretion up-regulation of complement receptor type 3 and superoxide anion production are stimulated by mastoparan. Biochem J. 1992 Mar 1;282 (Pt 2)(Pt 2):3937. doi: 10.1042/bj2820393. PubMed PMID: 1312328 ; PubMed Central PMCID: PMC1130791.

87. Tisch D, Sharoni Y, Danilenko M, Aviram I. The assembly of neutrophil NADPH oxidase: effects of mastoparan and its synthetic analogues. Biochem J. 1995 Sep1;310 (Pt 2)(Pt 2):715-9. doi: 10.1042/bj3100715. PubMed PMID: 7654216 ; PubMed Central PMCID: PMC1135954.

88. Tisch-Idelson D, Fridkin M, Wientjes F, Aviram I. Structure-function relationship in the interaction of mastoparan analogs with neutrophil NADPH oxidase. Biochem Pharmacol. 2001 May 1;61(9):1063-71. doi: 10.1016/s0006-2952(01)00561-5. PubMed PMID: 11301039.

89. Wu TM, Chou TC, Ding YA, Li ML. Stimulation of TNF-alpha, IL-1beta and nitrite release from mouse cultured spleen cells and lavaged peritoneal cells by mastoparan M. Immunol Cell Biol. 1999 Dec;77(6):476-82. doi: 10.1046/j.1440-1711.1999.00847.x. PubMed PMID: 10571667.

90. Moerman L, Bosteels S, Noppe W, Willems J, Clynen E, Schoofs L, et al. Antibacterial and antifungal properties of alpha-helical, cationic peptides in the venom of scorpions from southern Africa. Eur J Biochem. 2002 Oct;269(19):4799-810. doi: 10.1046/j.1432-1033.2002.03177.x. PubMed PMID: 12354111.
91. Willems J, Moerman L, Bosteels S, Bruyneel E, Ryniers F, Verdonck F. Parabutoporin--an antibiotic peptide from scorpion venom--can both induce activation and inhibition of granulocyte cell functions. Peptides. 2004 Jul;25(7):1079-84. doi: 10.1016/j.peptides.2004.04.008. PubMed PMID: 15245865

92. Moerman L, Verdonck F, Willems J, Tytgat J, Bosteels S. Antimicrobial peptides from scorpion venom induce $\mathrm{Ca}(2+)$ signaling in $\mathrm{HL}-60$ cells. Biochem Biophys Res Commun. 2003 Nov 7;311(1):90-7. doi: 10.1016/j. bbrc.2003.09.175. PubMed PMID: 14575699.

93. Remijsen Q, Vanden Berghe T, Parthoens E, Asselbergh B, Vandenabeele P, Willems J. Inhibition of spontaneous neutrophil apoptosis by parabutoporin acts independently of NADPH oxidase inhibition but by lipid raftdependent stimulation of Akt. J Leukoc Biol. 2009 Mar;85(3):497-507. doi: 10.1189/jlb.0908525. PubMed PMID: 19095734.

94. Remijsen Q, Verdonck F, Willems J. Parabutoporin, a cationic amphipathic peptide from scorpion venom: much more than an antibiotic. Toxicon. 2010 Feb-Mar;55(2-3):180-5. doi: 10.1016/j.toxicon.2009.10.027. PubMed PMID: 19874840

95. Remijsen QFM, Fontayne A, Verdonck F, Clynen E, Schoofs L, Willems J. The antimicrobial peptide parabutoporin competes with $\mathrm{p} 47$ (phox) as a PKC-substrate and inhibits NADPH oxidase in human neutrophils. FEBS Lett. 2006 Nov 13;580(26):6206-10. doi: 10.1016/j.febslet.2006.10.024. Epub 2006 Oct 19. PubMed PMID: 17069809.

96. Assumpcao TCF, Ribeiro JMC, Francischetti IMB. Disintegrins from hematophagous sources. Toxins (Basel). 2012 May;4(5):296-322. doi: 10.3390/toxins4050296. PubMed PMID: 22778902. PubMed Central PMCID: PMC3386632.

97. David V, Succar BB, de Moraes JA, Saldanha-Gama RFG, Barja-Fidalgo C, Zingali RB. Recombinant and chimeric disintegrins in preclinical research. Toxins (Basel). 2018 Aug 7;10(8):321. doi: 10.3390/toxins10080321. PubMed PMID: 30087285 ; PubMed Central PMCID: PMC6116119.

98. Coelho AL, de Freitas MS, Oliveira-Carvalho AL, Moura-Neto V, Zingali RB, Barja-Fidalgo C. Effects of jarastatin, a novel snake venom disintegrin, on neutrophil migration and actin cytoskeleton dynamics. Exp Cell Res. 1999 Sep15;251(2):379-87. doi: 10.1006/excr.1999.4583. PubMed PMID: 10471323.

99. Mariano-Oliveira A, Coelho ALJ, Terruggi CHB, Selistre-de-Araújo HS, Barja-Fidalgo C, De Freitas MS. Alternagin-C, a nonRGD-disintegrin, induces neutrophil migration via integrin signaling. Eur J Biochem. 2003 Dec;270(24):4799-808. doi: 10.1046/j.1432-1033.2003.03867.x. PubMed PMID: 14653807.

100. Coelho ALJ, De Freitas MS, Mariano-Oliveira A, Rapozo DCM, Pinto LFR, Niewiarowski S, et al. RGD- and MLD-disintegrins, jarastatin and EC3, activate integrin-mediated signaling modulating the human neutrophils chemotaxis, apoptosis and IL-8 gene expression. Exp Cell Res. 2004 Jan 15;292(2):371-84. doi: 10.1016/j.yexcr.2003.09.013. PubMed PMID: 14697344.

101. Tseng YL, Peng HC, Huang TF. Rhodostomin, a disintegrin, inhibits adhesion of neutrophils to fibrinogen and attenuates superoxide production. J Biomed Sci. 2004 Sep-Oct;11(5):683-91. doi: 10.1007/BF02256134. PubMed PMID: 15316144.

102. Saldanha-Gama RF, Moraes JA, Mariano-Oliveira A, Coelho AL, Walsh EM, Marcinkiewicz C, et al. Alpha(9)beta(1) integrin engagement inhibits neutrophil spontaneous apoptosis: involvement of $\mathrm{Bcl}-2$ family members. Biochim Biophys Acta. 2010 Jul;1803(7):848-57. doi: 10.1016/j. bbamcr.2010.03.012. PubMed PMID: 20362630. 